\title{
LOWER PALAEOZOIC GEOLOGY OF THE WESTERN PART OF THE NORTH GREENLAND FOLD BELT
}

\author{
Peter R. Dawes
}

\section{Introduction}

In the summers 1965 and 1966 reconnassance mapping of $10000 \mathrm{~km}^{2}$ of the rarely visited north coast of North Greenland was carried out. In 1965 the investigations were restricted to Hall Land (fig. 3) with a view of obtaining an insight into the stratigraphy of the Ordovician-Silurian succession, while in 1966 work centred on Nyeboe Land and Hendrik Island with cursory examination of the north-west coast of Wulff Land and the islands in Sherard Osborn Fjord. Both the unfolded rocks of the south towards the Inland Ice and the folded rocks of the northern coast bordering the Robeson Channel and the Arctic Ocean were studied and in the two summers a broad view of the western part of the North Greenland fold belt i.e. west of Peary Land, has been ob ained.

This work formed the Danish part of Operation Grant Land; an air supported geological reconnaissance investigation of some $64000 \mathrm{~km}^{2}$ of northern Ellesmere Island and North Greenland, organised by the Geological Survey of Canada and led by Dr R. L. Christie.

The rocks

A sedimentary succession of at least $2500 \mathrm{~m}$ exists in the area and this varies markedly in facies, both laterally and vertically.

The oldest rocks exposed, possibly Cambrian in age, are unfossiliferous pinkish-white quartzites and quartzitic conglomerates and these form a striking succession on the north-west coast of Wulff Land. In northern Nyeboe Land, possible late-Cambrian rocks are represented by some grey and yellow dolomites containing in part a trilobite fauna. These dolomites pass upward into Ordovician limestones and dolomitic limestones of many types ncluding some conglomerates and limestone breccias. Ordovician dolomites, characterised by a fauna of brachiopods and cephalopods, form the base of the succession in southern Nyeboe, Warming and Hall Lands, north of the Inland Ice and these rocks can be correlated with the black dolomites forming the lowest part of the succession on the northern coast of Hall Land.

Silurıan rocks differ strıkingly in facies in the northern and southern 


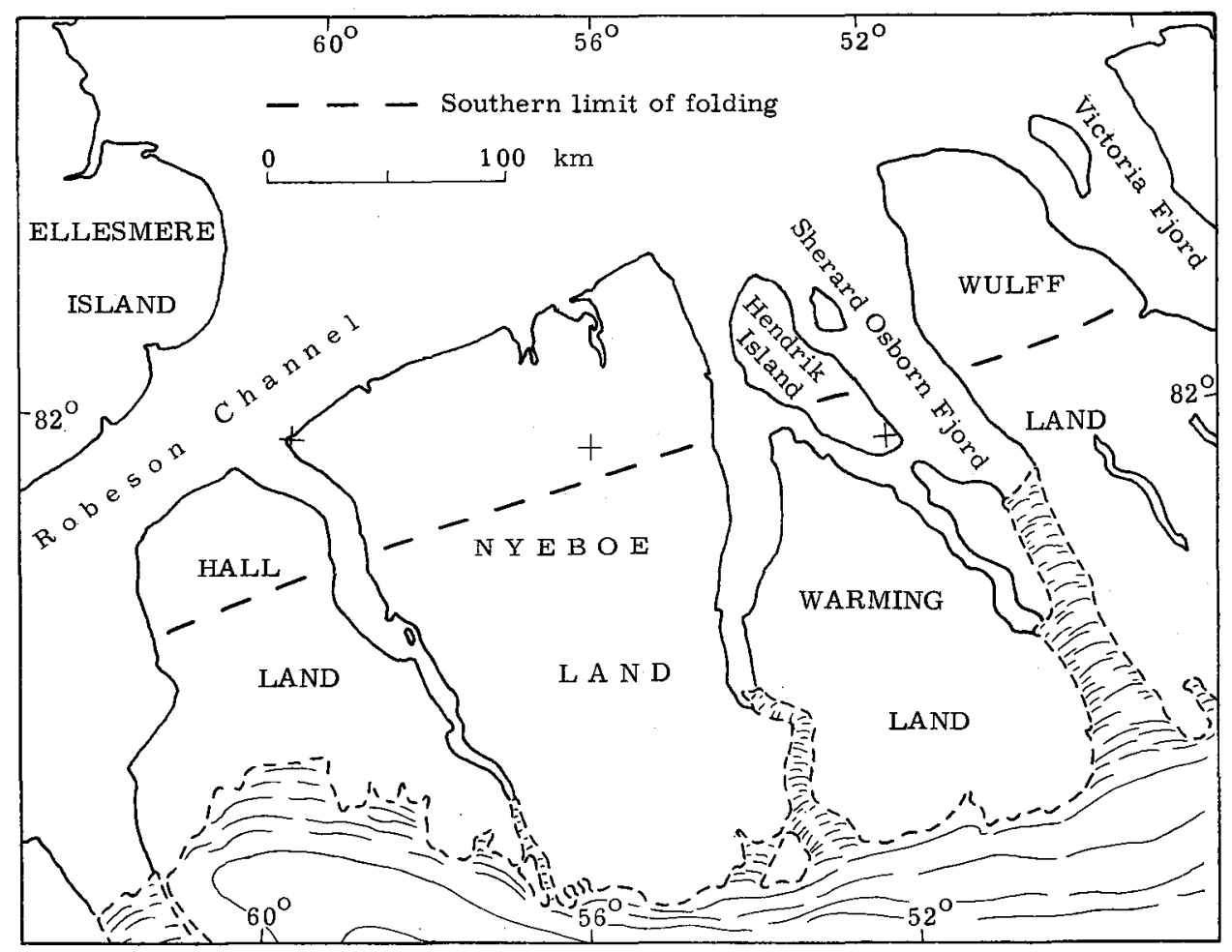

Fig. 3.

parts of the fold belt. The black Ordovician dolomites of the south pass upward into lighter-coloured massive Silurian limestones containing an abundant fauna of corals, crinoids, brachiopods, gastropods, cephalopods and trilobites. The youngest Silurian rocks in the south are calcareous shales and black compact limestones containing a dense fauna of brachiopods, trilobites, corals and crino1ds. The Ordovician dolomites of the northern part of the fold belt pass upward into a thick sequence of Silurian clastic rocks. These rocks can be referred to the Cape Rawson Group of Ellesmere Island, a term coined by Feilden and De Rance (1878) and adopted by Christie (1964) as a reconnaissance term. The lower part of the series contains calcareous sandstones and shales and the top is a turbidite sequence displaying excellent sedimentary structures.

On Hendrik Island, the Silurian sandstone sequence contains a distinct conglomerate zone up to $250 \mathrm{~m}$ thick - termed here the Hendrik Conglomerate. It is composed mainly of pebbles of coloured chert and quartzite but some pebbles of granite and gneiss presumably from the Precambrian basement 
exist. Lying above the conglomerate is a sequence of calcareous shales and black graptolitic shales.

The facies boundary between the Silurian limestones of the south and the clastic rocks of the north is marked by a transition from pure carbonate rocks to sandstones through calcareous siltstones, platy limestones and calcareous sandstones.

It seems necessary to critically revise Koch's (1929) division of the Lower Palaeozoic rocks in this part of North Greenland. In Nyeboe Land it is impossible to recognise the Offley Island Formation and the Cape Tyson Formation as distinct units and there is no marked unconformity separating the Ordovician rocks from the Silurian. Koch's Lower Palaeozoic Polaris Harbour Formation was found in its type locality to consist of Quaternary moraines.

The structures

The boundary between folded and unfolded rocks is well-defined and it can be traced from northern Polaris Bay in western Hall Land, across Nyeboe Land, Hendrik Island and Wulff Land striking in a general ENE direction. Fold-zones characterised by fold-style can be recognised parallel to this boundary. These zones are best seen in Nyeboe Land where in the south the rocks vary from flat-lying to gently dipping north-westwards. These pass north-westwards into zones characterised by monoclines, then asymmetrical folds and farther to the north-west by isoclinal and chevron folding. Fold axes trend east to north-east. The folds are commonly overturned to the northwest with axial planes dipping south-eastwards.

The age of the main folding cannot be accurately determined since no Upper Palaeozoic or Mesozoic rocks exist in the area. The youngest sediments of the area are Wenlockian in age and the folding is thus post-Wenlockian.

Faults are restricted in occurrence to the folded northern part of the area and are especially conspicuous breakng up the sandstone succession in north-western Nyeboe Land. Some thrusts, commonly parallel to lithological bedding, occur in northern Nyeboe Land and Hall Land. Some of these are associated structurally with the main folding; others appear to post-date the tectonics and may be due to post-Palaeozolc deformation. Haller and Kulp (1962) have interpreted all the thrusts as Tertiary post-dating the main folding. This is difficult to substantiate. 


\section{Metamorphism}

The metamorphic grade of the rock succession is very low and fossils are preserved even in the folded rocks. Only in the northern part of Nyeboe Land do the rocks take on a metamorphic appearance. Here the sandstones have developed a schistosity which seems to be connected with a secondary production of mica. The presence of these low grade metamorphic rocks in the northern part of the folded area may indicate an increase in metamorphic grade northwards. This simulates the trend noted by Ellitsgaard-Rasmussen (1955) and Fränkl (1955) in Peary Land to the east where the degree of metamorphism increases northwa d towards the assumed centre of the fold belt in the Arct1c Ocean.

\section{Basic intrusions}

No $b$ : sic intrusions were observed "on the ground" in the area mapped but from the air basic dykes, apparently undeformed, were noted on the west side of Victoria Fjord (Wulff Land) during a reconnaissance flight to Peary Land and these must represent the westernmost intrusives in the North Greenland fold belt.

\section{Geological setting}

The area investigated bridges two geological boundaries; the tectonic boundary between folded and unfolded rocks an that between the clastic facies of sediments and the more shelf-type carbonate rocks. The rocks are miogeosynclinal in type and can be regarded as forming the southern border of the so-called "Franklınian geosyncline". The two boundaries are clear and mappable and they thus provide a means of comparison with the geology across the Robeson Channel in Ellesmere Island in respect to the tectonic relationship between Greenland and Canada.

\section{References}

Christie, R. L. (1964) Geological reconnaissance of northeastern Ellesmere Island District of Franklin. Geol. Surv. Canada, Memoir 331, 79pp.

Ellitsgaard Rasmussen, K. (1955) Features of the geology of the Folding Range of Peary Land North Greenland. Med Grфnland, Bd 127, Nr. 7. 
Feilden, H.W. and De Rance, C. E. (1878) Geology of the coasts of the Arctic Lands visited by the Late British Expedition under Captain Sir George Nares, R. N., K.C.B., F.R.S. Quart. J. geol. Soc. Lond., Vol. $34,556-567$.

Fränk1, E. (1955) Rapport über die Durchquerung von Nord Peary Land (Nordgrönland) im Sommer 1953. Medd. Grфnland, Bd. 103, Nr. 8.

Haller, J. and Kulp, J. L. (1962) Absolute age determinations in East Greenland. Medd. Grфnland, Bd. 171, Nr.1.

Koch, L. (1929) Stratigraphy of Greenland, in Geology of Greenland. Medd Grфnland, Bd. 73, Afd.2, Nr.2.

NEW MAPPING ON SVARTENHUK PENINSULA

T.C.R. Pulvertaft and D. B. Clarke

Svartenhuk, although petrographically the best known of the West Greenland basalt areas, was until now the least satisfactorly mapped. The accounts of Rosenkrantz et al. (1942) and Noe-Nygaard (1942) were written before either accurate topographical maps or aerial photographs of the area were available and thus the accompanying geological maps are of a very generalised nature. Therefore, in order that the area could be satisfactorily represented on the Survey 1:500 000 sheets, it was necessary to remap it on new photogrammetric topographical maps, making full use of aerial photographs. This was our first task.

The second objective was to enable one of us (D. B. C.) to collect basalts for comparison with the Tertiary lavas on the east coast of Baffin Island, rocks which he has been studying for the last two years. At a time of increasing interest in continental drift in the North Atlantic and CanadianDanish collaboration in the study of the Wegener Fault between NW Greenland. and Ellesmere Island, a comparison of the Cretaceous-Tertiary geology on either side of Baffin Bay is obviously of much importance. 